\title{
Maatalousyrittäjien työurien lyhenemisen syyt ja kustannustehokkaiden toimenpiteiden kehittäminen työurien pidentämiseen
}

\author{
Janne Karttunen $^{1)}$, Jarkko Leppälä ${ }^{2)}$ ja Risto Rautiainen ${ }^{3)}$ \\ ${ }^{1)}$ TTS - Työtehoseura, PL 5, 05201 Rajamäki, janne.karttunen@tts.fi \\ ${ }^{2)}$ Maa- ja elintarviketalouden tutkimuskeskus MTT, Latokartanonkaari 9, 00790 Helsinki, \\ jarkko.leppala@mtt.fi \\ ${ }^{3)}$ The University of Nebraska, College of Public Health, Department of Environmental, Agricultural \\ and Occupational Health, Omaha, Nebraska 68105, USA sekä Maa- ja elintarviketalouden tutki- \\ muskeskus MTT, rrautiainen@unmc.edu
}

\section{Tiivistelmä}

Maatalous on yksi vaarallisimmista toimialoista, ja työtapaturmat sekä ammattitaudit aiheuttavat vuosittain satoja tapaturma- ja työkyvyttömyyseläkkeelle siirtymisiä. Myös luopumis- ja eläkepäätösten taustalla voi olla sairauden tai vamman vuoksi heikentynyt työkyky. Tämä tutkimus tähtää maatalousyrittäjien työurien vahvistamiseen ja pidentämiseen. Tutkimuksessa muun muassa selvitetään ja luokitellaan työurien lyhenemisen keskeisimmät syyt.

Maatalousyrittäjien eläkelaitoksesta hankitussa tilastoaineistossa on vuosia 2008-2012 koskien yhteensä 4088 eläkepäätöstä kokonaiskustannuksiltaan runsaat 60 miljoonaa euroa. Päätökset jakaantuvat kappalemääräisesti seuraavasti: täysiä työkyvyttömyyseläkkeitä $1971 \mathrm{kpl}$, osatyökyvyttömyyseläkkeitä $522 \mathrm{kpl}$, täysiä kuntoutustukia $1337 \mathrm{kpl} \mathrm{ja} \mathrm{osakuntoutustukia} 258 \mathrm{kpl}$. Aineistossa on yhteensä 3132 henkilöä, koska sama henkilö on voinut saada ko. aikajaksona yhdestä neljään päätöstä.

Yleisimmät kansainvälisen ICD-10-tautiluokituksen pääluokat täydelle työkyvyttömyyseläkkeelle olivat tuki- ja liikuntaelinten (tule) sairaudet (41,2\%) kuten polven nivelrikko, nikamavälilevyjen sairaudet ja hartianseudun sairaudet; mielenterveyden häiriöt $(18,2 \%)$ kuten masennustila ja toistuva masennus; verenkiertoelinten sairaudet $(10,5 \%)$ kuten sydänsairaudet; hermoston sairaudet $(8,1 \%)$ kuten Parkinsonin tauti, kasvaimet $(7,7 \%)$ kuten rinnan pahanlaatuiset kasvaimet, sekä vammat, myrkytykset yms. sairaudet $(5,6 \%)$ kuten hartianseudun ja olkavarren vammat. Eläkekustannukset jakaantuivat likipitäen samoissa suhteissa kuin eläkepäätökset edellä mainittujen pääluokkien kesken.

Verrattaessa maatalousyrittäjille myönnettyjen täysien työkyvyttömyyseläkkeiden yleisimpiä syitä Suomen koko työväestöstä työkyvyttömyyseläkkeelle siirtymisen syihin voidaan todeta, että yleisimmät tautiluokat ovat lähes samat. Merkittävimmät erot ovat, että koko työväestöön verrattuna maatalousyrittäjillä erityisesti tule-sairaudet sekä myös verenkiertoelinten sairaudet ovat yleisempiä ja mielenterveyden häiriöt ovat selvästi harvinaisempia. Nämä erot voivat johtua esimerkiksi kuormittavista työolosuhteista maatalousyrityksissä ja toteamisharhasta.

Täysi työkyvyttömyyseläke myönnettiin keskimäärin 57 vuoden iässä. MYEL-vakuutetun työuran pituus oli myöntöhetkellä keskimäärin 29 vuotta. Miehet ja naiset eivät eronneet toisistaan näissä suhteissa. Vuosina 2008-2012 naisten suhteellinen osuus MYEL-vakuutetuista laski 34:stä 33 prosenttiin. Naisten suhteellinen osuus vaihteli työkyvyttömyyseläkkeiden tautiluokissa 24:n ja 46 prosentin välissä naisten ollessa yliedustettuina niistä useimmissa. Tämä voi johtua esimerkiksi siitä, että naisista suhteessa suurempi osa voi työskennellä karjatiloilla kuormittavissa työolosuhteissa.

Jatkossa muun muassa lasketaan eri syytekijöiden aiheuttamat menetykset henkilötyövuosina ja kustannuksina. Tuloksien perusteella laaditaan toimenpide-ehdotuksia, jotka priorisoidaan niiden potentiaalisen vaikuttavuuden perusteella. Tutkimus päättyy keväällä 2014.

Asiasanat: ammattitauti, eläke, maatalousyrittäjä, työtapaturma, vakuutus 


\section{Johdanto}

Työurien pidentäminen on noussut Suomessa kansalliseksi haasteeksi kaikilla toimialoilla ja myös maataloudessa. Maatalousyrittäjien ja heidän perheenjäsentensä työtapaturmat ja ammattitaudit aiheuttavat tapaturma- ja työkyvyttömyyseläkkeitä. Myös luopumistuissa ja varhaisissa vanhuuseläkkeissä saattaa olla taustalla vakuutetun heikentynyt työkyky sairauden tai vamman vuoksi (Leskinen 2004). Ennenaikainen eläkkeelle siirtyminen voi lyhentää maatalousyrittäjän työuraa merkittävästi.

Suomessa Maatalousyrittäjien eläkelaitos (jatkossa: Mela) huolehtii muun muassa lakisääteisistä maatalousyrittäjien työeläke- ja työtapaturmavakuutuksista. Vuodesta 2000 lähtien sekä eläkevakuutettujen että eläkkeellä olevien maatalousyrittäjien määrät ovat laskeneet yli neljänneksellä, ja eläkkeensaajia on noin kaksinkertainen määrä vakuutettuihin verrattuna (Mela 2011a). Eläkkeistä johtuva kustannuspaine rasittaa sekä maatalouden kannattavuutta että yhteiskuntaa. Työurien pidentäminen on siksi keskeinen tavoite maatalousyrittäjien sosiaaliturvan kehittämisessä.

Melan julkaisemat maatalousyrittäjien tapaturma- ja ammattitautitilastot eli MATA-tilastot sekä Melan rahoittamat tutkimukset ovat kartoittaneet maatalousyrittäjille ja heidän perheenjäsenilleen korvattujen työtapaturmien ja ammattitautien luonnetta sekä tilastoituja aiheuttajia yksityiskohtaisesti (Rautiainen ym. 2009, Mela 2011b, Karttunen ja Rautiainen 2013a ja 2013b, Leppälä ym. 2013).

Työkyvyttömyyseläkkeelle siirtymisen syyt maamme kaikkia työeläkevakuutettuja koskien tiedetään: tuki- ja liikuntaelinten sairaudet, mielenterveyden ja käyttäytymisen häiriöt, verenkiertoelinten sairaudet, hermoston sairaudet sekä vammat ja myrkytykset aiheuttivat yhteensä yli neljä viidesosaa (85 \%) työkyvyttömyyseläkkeistä vuonna 2009 (Pensola ym. 2010). Maatalousyrittäjien tapaturma- ja työkyvyttömyyseläkkeiden syyt, kustannukset ja menetetyt työvuodet eivät kuitenkaan ole yleisesti tiedossa.

Maatalousyrittäjille korvattujen työtapaturmien määrät ovat olleet laskussa ja hienoista laskua on ollut myös työtapaturmasuhteessa (Mela 2013a, 2013b). Vaikka trendi on positiivinen, vahinkosuhde on edelleen korkeampi kuin useimmilla muilla aloilla, ja korvauskustannuksissa ei ole ollut havaittavissa selvää laskua viime vuosina. Maatalousyrittäjille korvattujen työtapaturmien ja ammattitautien työuria lyhentävästä vaikutuksesta ei ole riittävästi tietoa. Tapaturmaeläke voi alkaa yrittäjäuran alkuvaiheessa korkealla työtulotasolla. Vahingoittuneen perheenjäsenet voivat myös jäädä vaille toimeentuloturvaa. Monissa tapauksissa yhdestä pitkään pysyvään työkyvyttömyyteen johtavasta työtapaturmasta tai ammattitaudista voi aiheutua erittäin merkittävät korvausmenot. Lisäksi kaikkiin työvahinkoihin liittyy epäsuoria kustannuksia ja menetyksiä vahingoittuneelle, yrittäjäperheelle, yritykselle ja yhteiskunnalle. Näiden menetysten arvoa on vaikea mitata.

Maatalousalalla on hyvät mahdollisuudet selvittää työurien pituuteen vaikuttavia tekijöitä, koska Mela-turva kattaa käytännössä koko maatalousyrittäjäväestön, ja merkittävät työuriin liittyvät tapahtumat ilmenevät vakuutus-, vahinkokorvaus- ja eläketapahtumina, jotka tilastoidaan yksityiskohtaisesti. Vahinkokorvausten ja eläkkeiden myöntöperusteet ja -määrät tunnetaan Melan tilastojen pohjalta hyvin. Työtapaturmien ja ammattitautien tilastointi sekä tehdyt tutkimukset ovat antaneet hyvän kuvan työvahinkojen syistä ja riskitekijöistä. Työkyvyttömyyseläkkeissä selvitetään työkyvyttömyyteen johtaneet sairaudet. Muissa eläkemuodoissa mahdollisia päätökseen vaikuttaneita sairauksia ei kuitenkaan yleensä selvitetä. Vaikka tietoa työurien lyhenemisen syistä on saatavilla, yleiskuva toimenpiteiden suunnittelua ja priorisointia varten ei kuitenkaan ole riittävän selvä.

Maatalousalan vaarallisuuden vuoksi työturvallisuus-, -terveys- ja -hyvinvointitekijät ovat tärkeitä työurien pituuteen vaikuttavia tekijöitä. Keskeinen ongelma työurien pidentämiseen tähtäävien toimenpiteiden suunnittelussa on, miten eri järjestelmiin kertyvä tieto saadaan koottua yhteismitallisesti päätöksenteon ja toimenpiteiden priorisoinnin tueksi.

\section{Tutkimuksen tavoite}

Tämä raportti perustuu Maa- ja elintarviketalouden tutkimuskeskus MTT:n ja TTS - Työtehoseuran yhteistutkimukseen "Maatalousyrittäjien työurien lyhenemisen syyt ja kustannustehokkaiden toimenpiteiden kehittäminen työurien pidentämiseen (Maaura-hanke)". Tutkimus päättyy keväällä 2014.

Tutkimus tähtää maatalousyrittäjien työurien vahvistamiseen ja pidentämiseen. Tutkimuksessa selvitetään ja luokitellaan maatalousyrittäjien työurien lyhenemisen keskeisimmät syyt. Tämän lisäksi osin lasketaan ja osin arvioidaan eri syytekijöiden aiheuttamat menetykset henkilötyövuosina ja kustannuksina. Kerättävän tiedon perusteella laaditaan toimenpide-ehdotuksia, jotka priorisoidaan niiden potentiaalisen vaikuttavuuden perusteella. 


\section{Aineisto ja menetelmät}

Melan tilastotiedoista vuosilta 2008-2012 kartoitetaan maatalousyrittäjien eläkkeiden lukumäärät ja työvuosien menettämiseen johtaneet syyt vamman tai sairauden lajin sekä Mela-turvan osa-alueen (ml. MATA-vahingot ja työkyvyttömyyseläkkeet) mukaan. Tilastoaineiston avulla selvitetään eri syistä ja eri Mela-turvan osa-alueilta menetetyt henkilötyövuodet. Näitä tietoja verrataan Suomen kaikkien työeläkevakuutettujen työkyvyttömyyseläkkeiden syihin.

Luokittelussa käytetään kansainvälistä ICD-10 -tautiluokituskoodia (THL 2011) ja muita käytettävissä olevia taustamuuttujia kuten vakuutetun ikää, sukupuolta ja vakuutusvuosia. Tavoitteena on laatia kattava kuvaus eri syistä johtuvista työvuosien menetyksistä ja tästä aiheutuvista kustannuksista. Tutkimusryhmä ei saa haltuunsa Melan asiakkaiden nimi- tai osoitetietoja.

Toimenpide-ehdotusten muodostamista varten järjestetään tutkimuksen lopussa työpaja, johon kutsutaan maatalousalan turvallisuusasiantuntijoita, joiden tehtäväksi asetetaan toimenpiteiden priorisoiminen. Priorisoinnin perustana toimii toisaalta tässä tutkimuksessa kerättävä tieto eri syistä johtuvista työvuosien menetyksistä sekä toisaalta asiantuntijoiden kokemus torjuntatoimenpiteiden soveltuvuudesta työuran keskeytyksistä johtuvien menetysten torjumisessa.

\section{Tulokset}

Melasta hankitussa tilastoaineistossa on vuosia 2008-2012 koskien yhteensä 4088 maatalousyrittäjien eläkepäätöstä tähänastisilta kokonaiskustannuksiltaan runsaat 60 miljoonaa euroa. Päätökset jakaantuivat kappalemääräisesti seuraavasti: täysiä työkyvyttömyyseläkkeitä $1971 \mathrm{kpl}$, osatyökyvyttömyyseläkkeitä $522 \mathrm{kpl}$, täysiä kuntoutustukia $1337 \mathrm{kpl} \mathrm{ja} \mathrm{osakuntoutustukia} 258 \mathrm{kpl}$.

Tilastoaineistossa on yhteensä 3132 henkilöä, koska sama henkilö on voinut saada ko. aikajaksona yhdestä neljään päätöstä: esimerkiksi ensin kuntoutustukeen liittyviä päätöksiä ja niiden jälkeen päätöksen työkyvyttömyyseläkkeestä. Päätökset täysistä työkyvyttömyyseläkkeistä (taulukko 1) on kuitenkin tehty aina eri henkilöille.

Taulukko 1. Täydelle työkyvyttömyyseläkkeelle vuosina 2008-2012 siirtyneet maatalousyrittäjät, eläkkeiden syyt (ICD-10 -tautiluokka) ja tähänastiset kustannukset. Yleisimmät syyt on korostettu.

\begin{tabular}{rlrrrr}
\hline Ryhmä & Nimi ${ }^{1}$ & Kpl & $\%$ & Euroa & \% \\
\hline A00-B99 & Tartunta- ja loistaudit & 7 & 0,4 & 147037 & 0,4 \\
C00-D48 & Kasvaimet & $\mathbf{1 5 1}$ & $\mathbf{7 , 7}$ & $\mathbf{1 9 5 4} \mathbf{3 8 4}$ & $\mathbf{5 , 2}$ \\
D50-D89 & Veren ja verta muodostavien elinten sairaudet & 5 & 0,3 & 161791 & 0,4 \\
E00-E90 & Umpieritys-, ravitsemus- ja aineenvaihd. sair. & 35 & 1,8 & 823369 & 2,2 \\
F00-F99 & Mielenterveyden ja käyttäytymisen häiriö̈t & $\mathbf{3 5 8}$ & $\mathbf{1 8 , 2}$ & $\mathbf{6 ~ 6 1 7 ~ 2 0 9}$ & $\mathbf{1 7 , 4}$ \\
G00-G99 & Hermoston sairaudet & $\mathbf{1 6 0}$ & $\mathbf{8 , 1}$ & $\mathbf{3 3 6 9} \mathbf{9 2 0}$ & $\mathbf{8 , 9}$ \\
H00-H59 & Silmän ja sen apuelinten sairaudet & 5 & 0,3 & 85025 & 0,2 \\
H60-H95 & Korvan ja kartiolisäkkeen sairaudet & 2 & 0,1 & 24980 & 0,1 \\
I00-I99 & Verenkiertoelinten sairaudet & $\mathbf{2 0 7}$ & $\mathbf{1 0 , 5}$ & $\mathbf{4 ~ 2 5 7 ~ 4 3 1}$ & $\mathbf{1 1 , 2}$ \\
J00-J99 & Hengityselinten sairaudet & 63 & 3,2 & 1229313 & 3,2 \\
K00-K93 & Ruoansulatuselinten sairaudet & 14 & 0,7 & 226388 & 0,6 \\
L00-L99 & Ihon ja ihonalaiskudoksen sairaudet & 9 & 0,5 & 121318 & 0,3 \\
M00-M99 & Tuki- ja liikuntaelinten sairaudet & $\mathbf{8 1 3}$ & $\mathbf{4 1 , 2}$ & $\mathbf{1 6 ~ 5 8 9 ~ 5 0 3}$ & $\mathbf{4 3 , 7}$ \\
N00-N99 & Virtsa- ja sukupuolielinten sairaudet & 12 & 0,6 & 185811 & 0,5 \\
O00-O99 & Raskaus, synnytys ja lapsivuoteus & - & - & - & - \\
P00-P96 & Eräät perinataaliaikana alkanet tilat & - & - & - & - \\
Q00-Q99 & Synnynnäiset epämuodostumat,... & 6 & 0,3 & 135548 & 0,4 \\
R00-R99 & Muualla luokittamattomat oireet,... & 10 & 0,5 & 335257 & 0,9 \\
S00-T98 & Vammat, myrkytykset ja eräät muut... & $\mathbf{1 1 1}$ & $\mathbf{5 , 6}$ & $\mathbf{1 6 3 0 1 0 8}$ & $\mathbf{4 , 3}$ \\
U00-U99 & Diagnoosikoodeja erityistapauksille & - & - & - & - \\
V01-Y98 & Vammojen, sairauksien... & - & - & - & - \\
Z00-Z99 & Tekijöitä jotka vaikuttavat terveydentilaan... & 3 & 0,2 & 43011 & 0,1 \\
\hline
\end{tabular}

${ }^{1}$ ICD-10 -tautiluokituskoodisto löytyy Suomeksi esimerkiksi lähteestä THL (2011). 
Yleisimmät ICD-10-tautiluokituksen pääluokat täydelle työkyvyttömyyseläkkeelle olivat tukija liikuntaelinten (tule) sairaudet kuten polven nivelrikko, nikamavälilevyjen sairaudet ja hartianseudun sairaudet; mielenterveyden häiriöt kuten masennustila ja toistuva masennus; verenkiertoelinten sairaudet kuten sydänsairaudet; hermoston sairaudet kuten Parkinsonin tauti; kasvaimet kuten rinnan pahanlaatuiset kasvaimet, sekä vammat, myrkytykset yms. sairaudet kuten hartianseudun ja olkavarren vammat. Edellä mainitut kuusi pääluokkaa kattavat valtaosan (91,3 \%) tarkastelujakson aikana myönnetyistä täysistä työkyvyttömyyseläkkeistä.

Täysistä työkyvyttömyyseläkkeistä aiheutui vuoden 2012 loppuun mennessä yhteensä lähes 38 miljoonan euron eläkekustannukset. Kuten taulukosta 1 nähdään, kustannukset jakaantuivat likipitäen samoissa suhteissa kuin yksittäiset eläkepäätökset edellä mainittujen pääluokkien kesken. Osatyökyvyttömyyseläkkeistä aiheutui puolestaan runsaan 5,5 miljoonan euron kustannukset. Täysistä kuntoutustuista aiheutui runsaan 15 miljoonan euron kustannukset ja osakuntoutustuista runsaan miljoonan euron kustannukset.

Täysi työkyvyttömyyseläke myönnettiin keskimäärin 57 vuoden iässä (mediaani 59, moodi 60, minimi 26 ja maksimi 63 vuotta). MYEL-vakuutetun työuran pituus oli myöntöhetkellä keskimäärin 29 vuotta (mediaani 30, moodi 38, minimi 2 ja maksimi 43 vuotta). Miehet ja naiset eivät eronneet toisistaan näissä suhteissa.

Tarkasteltaessa täysien työkyvyttömyyseläkkeiden suhteen yleisimpiä ICD-10 -tautiluokkia voidaan todeta, että naisten suhteellinen osuus oli selvästi suurin tule-sairauksissa ja pienin verenkiertoelinten sairauksissa (taulukko 2).

Taulukko 2. Täydelle työkyvyttömyyseläkkeelle vuosina 2008-2012 siirtyneiden maatalousyrittäjien sukupuolijakauma kuudessa yleisimmässä ICD-10 -tautiluokassa.

\begin{tabular}{rlrrrr}
\hline Ryhmä & Nimi & \multicolumn{2}{c}{ Miehet } & \multicolumn{2}{c}{ Naiset } \\
& & $\mathrm{kpl}$ & $\%$ & $\mathrm{kpl}$ & $\%$ \\
\hline M00-M999 & Tuki- ja liikuntaelinten sairaudet & 441 & 54,2 & 372 & 45,8 \\
F00-F99 & Mielenterveyden ja käyttäytymisen häiriöt & 229 & 64,0 & 129 & 36,0 \\
I00-I99 & Verenkiertoelinten sairaudet & 158 & 76,3 & 49 & 23,7 \\
G00-G99 & Hermoston sairaudet & 101 & 63,1 & 59 & 36,9 \\
C00-D48 & Kasvaimet & 92 & 60,9 & 59 & 39,1 \\
S00-T98 & Vammat, myrkytykset ja eräät muut ... & 75 & 67,6 & 36 & 32,4 \\
\hline
\end{tabular}

\section{Tuloksien tarkastelu ja johtopäätökset}

Verrattaessa maatalousyrittäjien täysien työkyvyttömyyseläkkeiden yleisimpiä syitä Suomen kaikkien työeläkevakuutettujen joukosta vuonna 2009 työkyvyttömyyseläkkeelle siirtyneiden syihin voidaan todeta, että yleisimmät tautiluokat ovat lähes samat (Pensola ym. 2010). Merkittävimmät erot ovat, että maatalousyrittäjillä erityisesti tule-sairaudet ( $44 \%$ vs. $34 \%$ ) sekä myös verenkiertoelinten sairau$\operatorname{det}(11 \%$ vs. $8 \%)$ ovat yleisempiä ja mielenterveyden häiriöt ovat selvästi harvinaisempia (17\% vs. $30 \%)$ työkyvyttömyyseläkkeiden syitä.

Tule-sairaudet ovat merkittävin yksittäinen tautiluokka työkyvyttömyyseläkkeistä aiheutuneiden kustannusten suhteen. Tule-sairauksien yleisyys maatalousyrittäjien työkyvyttömyyseläkkeiden syynä voi johtua fyysisesti kuormittavien työolosuhteiden lisäksi siitä, että tule-sairaudet voivat tulla helpommin diagnosoiduiksi kuin esimerkiksi mielenterveyden häiriöt (toteamisharha). Etenevästä rakennemuutoksesta ja karjanhoitotöiden koneellistamisesta huolimatta erityisesti lypsykarjatalous sisältää edelleen runsaasti vähintään keskiraskasta lihastyötä ja lisäksi staattisia työasentoja (Douphrate ym. 2013).

Melan (2013b) tilastojen mukaan vuosina 2008-2012 naisten suhteellinen osuus MYEL-vakuutetuista laski 34:stä 33 prosenttiin. Näin ollen naiset olivat yliedustettuina kuudesta yleisimmästä tautiluokasta erityisesti tule-sairauksissa. Tämä voi johtua esimerkiksi siitä, että työkyvyttömyyseläkkeelle joutuneet naiset ovat saattaneet työurallaan tehdä erityisesti kuormittavia karjanhoitotöitä. Tätä käsitystä tukee Karttusen ja Tuuren (2013) tutkimus, jonka mukaan naisten suhteellinen työpanos on merkittävin maa- ja metsätaloustöissä juuri karjanhoitotöissä. Naisten ennenaikainen työkyvyn aleneminen on todettu myös aiemmissa tutkimuksissa (Karttunen ja Rautiainen 2009): työkykyindeksillä mitattu työkyky aleni lypsykarjatiloilla työskentelevillä naisilla miehiä nopeammin 
ja erityisesti 45 ikävuoden jälkeen.

Tämä tutkimus tulee tuottamaan tietoa maatalousyrittäjien työkyvyttömyys- ja tapaturmaeläkkeiden syistä ja kustannuksista sekä toimenpiteistä, joiden avulla kyetään vähentämään ennenaikaista eläköitymistä ja pidentämään maatalousyrittäjien työuria. Maatalousneuvonnan ja -koulutuksen lisäksi tietoja voidaan hyödyntää muun muassa maatalousyrittäjien työterveyshuollossa, työkykyä ylläpitävässä toiminnassa sekä varhaiskuntoutuksessa.

\section{Kiitokset}

Kirjoittajat kiittävät Maatalousyrittäjien eläkelaitosta, jonka työturvallisuusapurahalla rahoitetaan pääosa tästä tutkimuksesta.

\section{Kirjallisuus}

Douphrate, D.I., Lunner Kolstrup, C., Nonnenmann M.W., Jakob, M. \& Pinzke, S. 2013. Ergonomics in modern dairy practice: A review of current issues and research needs. J. Agromed. 18(3): 198-209.

Karttunen, J.P. \& Rautiainen, R.H. 2009. Work Ability Index among Finnish dairy farmers. J. Agric. Saf. Health 15(4): 353-364.

Karttunen, J.P. \& Rautiainen, R.H. 2013a. Occupational injury and disease incidence and risk factors in Finnish agriculture based on 5-year insurance records. J. Agromed. 18(1): 50-64.

Karttunen, J.P. \& Rautiainen, R.H. 2013b. Distribution and characteristics of occupational injuries and diseases among farmers: a retrospective analysis of workers' compensation claims. Am. J. Ind. Med. 56(8): 856869.

Karttunen, J. \& Tuure, V.-M. 2013. Työnjako perustuotantoa harjoittavissa ja monialaisissa maatalousyrityksissä. TTS:n tiedote. Maataloustyö ja tuottavuus (648) 6: 1-8.

Leppälä, J., Kauranen, I. \& Rautiainen, R. 2013. Effectiveness of occupational health service programmes in farmers' safety and security risk management. International Journal of Agricultural Management 2(3): 130-140.

Leskinen, J. 2004. Saloseudulta EU-isännäksi - lypsykarjayrittäjät muutosmurroksessa. Työ ja ihminen. Akateeminen väitöskirja. Helsinki. Työterveyslaitos. Tutkimusraportti 24: 1-153.

Mela. 2011a. Maatalousyrittäjien eläkelaitos. MYEL-piirin kehitys 1970 - 2020. Saatavilla internetistä: http://asp.hci.fi/mela/tilastot.nsf/349c295afc41d138c2256b480029204b/3d3f3bf78ecd0252c225718

03daac8? OpenDocument

Mela. 2011b. Maatalousyrittäjien eläkelaitos. Mata-vahingot. Saatavilla internetistä: http://asp.hci.fi/mela/ tilastot.nsf/Aikasarjat?OpenView $\&$ Start=1\&Count=30\&Expand=5\#5

Mela. 2013a. MATA-vahingot Saatavilla internetistä: http://asp.hci.fi/mela/tilastot.nsf/ 7355799fbb8212d4c2256b4800292031/e5c9becb5b531efbc2256957003b3670?OpenDocument

Mela. 2013b. Vakuutettujen maatalousyrittäjien lukumäärä vuoden lopussa. Saatavilla internetistä: http://asp.hci.fi/mela/tilastot.nsf/7355799fbb8212d4c2256b4800292031/26c2655525be249fc225684d004e3b29? OpenDocument

Pensola, T., Gould, R. ja Polvinen, A. 2010. Ammatit ja työkyvyttömyyseläkkeet. Masennukseen, muihin mielenterveyden häiriöihin sekä tuki- ja liikuntaelinten sairauksiin perustuvat eläkkeet. Sosiaali- ja terveysministeriön selvityksiä 16: 1-136. Saatavilla internetistä: http://www.stm.fi/ c/document_library/ get_file?folderId=1082856\&name=DLFE-11710.pdf

Rautiainen, L., Ledolter, J., Ohsfeldt, R., Donham. K. \& Zwerling, C. 2009. Risk factors for serious injury in Finnish agriculture. Am. J. Ind. Med. 52(5): 419-428.

THL. 2011. Tautiluokitus ICD-10. Luokitukset, termistöt ja tilasto-ohjeet. Terveyden ja hyvinvoinnin laitos. 3 . painos. 852 s. Saatavilla internetistä: http://www.thl.fi/thl-client/pdfs/15c30d65-2b96-41d7-aca8-1a05aa8a0a19 